Boletín de la Sociedad Geológica Mexicana

\title{
Landslide inventory map of Guadalupe Range, north of the Mexico Basin
}

\author{
Armando García-Palomo 1,2,*, Víctor Carlos-Valerio², Celia López-Miguel², \\ Adriana Galván-García ${ }^{2}$, Aline Concha-Dimas ${ }^{1}$
}

${ }^{1}$ Departamento de Geología Regional, Instituto de Geología, Universidad Nacional Autónoma de México Coyoacán, 04510, Mexico D.F.

${ }^{2}$ Servicio Geológico Metropolitano, Instituto de Geología, Universidad Nacional Autónoma de México Coyoacán, 04510, Mexico D.F. y

Dirección General de Protección Civil Gobierno del Distrito Federal

*apalomo@geologia.unam.mx

\begin{abstract}
The Guadalupe Range (GR) is one of the several volcanic chains in the Mexico Basin and is located in its north-central portion. Four municipalities of the State of Mexico -Tlalnepantla, Tultitlan, Ecatepec, Coacalco- and one precinct in Mexico City -Delegation Gustavo A. Madero- surround the Guadalupe range. During the last decades the settlements in these areas have experienced substantial population growth. In the 1960's, the communities had 744,905 people, and by 2000, the population was of 4152,350 peoples. Nowadays, the population of these municipalities is growing towards the GR. However, the natural conditions of GR such as its geology, geomorphology and climate; along with human factors such as deforestation, changes of original slope, heavy-traffic transit and mining, have create the conditions for the occurrence of landslides that affect the population of these areas.

We identified and characterized 206 landslide sites in the Guadalupe Ranges. The mechanism most frequently found was toppling and rock fall, followed by, wedge, translational and rotational failure, debris flow, creep or a combination of these mechanisms. Slope failures were identified through erosive landforms, horseshoe head and flanks and tectonic features such as fault scarpments and fractures. From the identified landslides, and the natural and human conditions that motivate their occurrence, it is established that a landslides seriously threaten the communities of Tlalnepantla, Ecatepec, Coacalco, Tultitlan and Gustavo A. Madero. According with adverse geological and geomorphic condition on Guadalupe range it is necessary to propose a landslides inventory map, goal of this paper.
\end{abstract}

Key words: Mexico Basin, Guadalupe Ranges, Landslides, horseshoe- shaped landform, faults.

\section{Resumen}

La Sierra de Guadalupe (SG) es una de varias cadenas volcánicas dentro de la Cuenca de México, localizada en la porción centronorte. Los municipios del Estado de México como Tlalnepantla, Tultitlan, Ecatepec, Coacalco y la Delegación Gustavo A. Madero del Distrito Federal han experimentado un crecimiento poblacional en las últimas décadas. En los años 60's los municipios tenían 744,905 personas y para el año 2000 fueron 4 152,350 personas. La población en esas regiones está creciendo hacia las laderas de la Sierra de Guadalupe. Sin embargo, las condiciones naturales de la Sierra de Guadalupe como las geológicas, geomorfológicas y climáticas aunado a los factores humanos como: deforestación, cambios de las condiciones originales de las pendientes, abundante transito pesado y explotación de minas a cielo abierto, determinan la presencia de deslizamientos de ladera que afectan a la población en esas localidades.

En este trabajo se identificaron 206 sitios de peligro por deslizamiento. El mecanismo más frecuente reconocido, es el volteo y caída de rocas, y en menor proporción deslizamiento por cuña, traslacional, rotacional flujo de detritos, creep o una combinación de esos mecanismos. El análisis realizado permite definir que los deslizamientos se localizan principalmente en zonas de circos de 
erosión sobre todo en las cabeceras y en los flancos de estos y, en zonas de alta pendiente y material triturado de las fallas que afectan a la Sierra de Guadalupe. Los municipios en orden de afectación por este tipo de fenómenos son Tlanepantla, Ecatepec, Coacalco y Tutltitlan y la Delegación Gustavo A. Madero. En conclusión, de acuerdo con las condiciones adversas de la Sierra de Guadalupe tanto geológicas como geomorfológicas motivó a la generación de un mapa de inventarios por deslizamiento de esta región.

Palabras clave: Cuenca de México, Sierra de Guadalupe, procesos de remoción en masa, estructuras en forma de herradura de caballo, fallas.

\section{Introduction}

The population in the metropolitan area has grown considerably in the last few decades. The growth has reached even the hills of Mexico City. Irregular settlements are common phenomenon on the Chichinautzin and Las Cruces ranges, and have also invaded the ranges inside the basin: the Sierra Santa Catarina and Guadalupe Ranges (GR) (Figure 1). This problem particularly accentuated in the GR, a small range rising in the northern central portion of Mexico City $\left(19^{\circ} 30^{\prime}, 19^{\circ} 38^{\prime} \mathrm{N}\right.$; $99^{\circ} 00$, $99^{\circ} 12^{\prime} \mathrm{W}$ ) (Figure 1 ). The GR has a maximum elevation of 3,010 $\mathrm{m}$ above sea level and is surrounded by Tlalnepantla, Tultitlán, Coacalco and Ecatepec municipalities belonging to the State of Mexico and Gustavo A. Madero, a precinct of Mexico City. The urban settlements have invaded creek valleys, ecological reserve zones, and the SG surroundings. Several flank failures in the surroundings have affected communities in the region. Rock falls and rockslides have occurred in La Pastora community at Cerro Chiquihuite (Espinosa-Hernandez, 2004; Servicio Geológico Metropolitano, 2001), in the highly fractured zone of Pico de Águila (Nieto-Obregón et al., 2000) or in the very unstable slopes of Cerro El Tenayo (Carlos-Valerio, 2003). In such cases, the morphological and geological conditions and the anthropogenic alteration of mountain slopes were favorable to the occurrence of landslides with adverse impact on the population. Phenomena of diverse origin have also influenced the landslide activity. For example, on August 25, 2003, a heavy rainfall triggered rock and soil avalanches, affecting houses in the Gustavo A. Madero zone. In addition, the region is located in a seismic active zone, several earthquakes have occurred in the region triggering landslides (Fraustro, 1999). One of the last seismic events occurred in November 15, 2001, $4.18 \mathrm{pm}$, with a magnitude of 3.5 , at a depth of $3 \mathrm{~km}$ and with an epicenter located at 19.55 latitude and -99.16 longitude, not far from the GR (Servicio Sismológico Nacional, 2001). Although no evident damage appeared in the zone, it is quite probable that the next seismic event would trigger landslides in the region. Due to the difficult conditions in the SG occasioned by the aspects discussed above, it is necessary to characterize and recognize the landslides occurred. Although a landslide maps of the region have been made (Lugo-Hubp and Salinas-Montes, 1996), they are of a general nature or represents only local areas (Fraustro, 1999). In this paper we present the landslide inventory map that recognized circa of 206 landslides zones including rock falls, landslides, toppling, and composite mechanisms that have affected the referred municipalities and could occur again.

\section{Methodology}

We performed a structural, geomorphologic map and a landslide inventory map of the study zone. The mapping was based on an interpretation of satellite image Landsat TM 7, with the composition of 4, 3, 2 (RGB) bands and the IDRISI software. We interpreted black and white aerial photographs 1: 37,500 scale. Topographic maps scale 1: 50,000 (Hoja Cuautitlán, INEGI, 1998) and 1:25,000 scale with $10-\mathrm{m}$ contour lines were used to place the information. In order to incorporate this information, we have also used the ILWIS 3.0 software to generate structural, morphological, slopes, shadow relief, altimetry and isohyetal maps. During field work every landslide was recognized and mapped and recorded with an individual location, failure mechanism (Hutchinson, 1988), potential triggering mechanism, direction of movement, degree of instability according to vegetation characteristics and the presence of loose blocks and close structures. All the locations and site characteristics were compiled and then we generated inventory map that shows the extent, spatial distribution of landslides, and type of failure mechanisms in the zone.

\section{Geological framework}

\subsection{Geology}

The Mexico Basin is located on the western edge of the eastern portion of the Trans-Mexican Volcanic Belt (TMVB). It has an average elevation of 2,240 masl and is bounded by several faulted volcanic ranges: the Pachuca range, with Oligocene volcanic rocks, to the north, the Las Cruces volcanic range, composed of Miocene-Pliocene andesitic rocks, to west, the Sierra Nevada, formed by Tláloc, Telapón, Iztaccíhuatl and Popocatépetl volcanoes, the east and by the late Pleistocene-Holocene Chichinautzin Volcanic Field to the south. The Mexico Basin is a volcanotectonic, endorheic, lacustrine basin. Within the Mexico Basin there are two main volcanic ranges; one of them is the Guadalupe Range (Figure 1). 


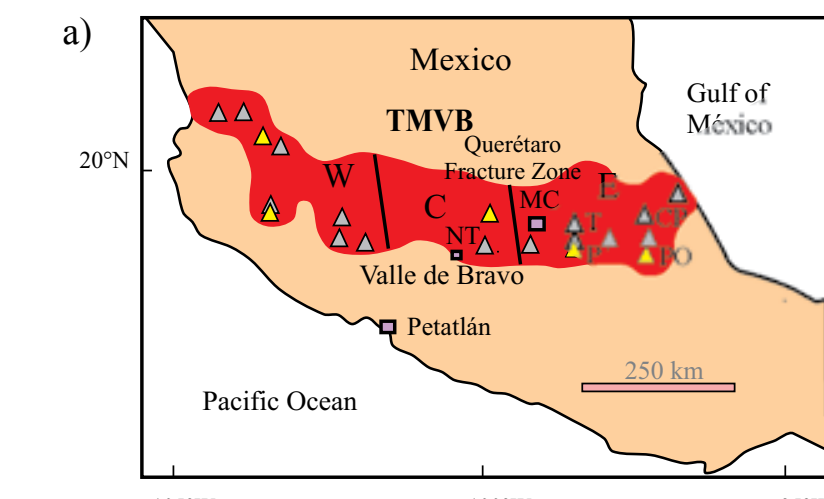

b)

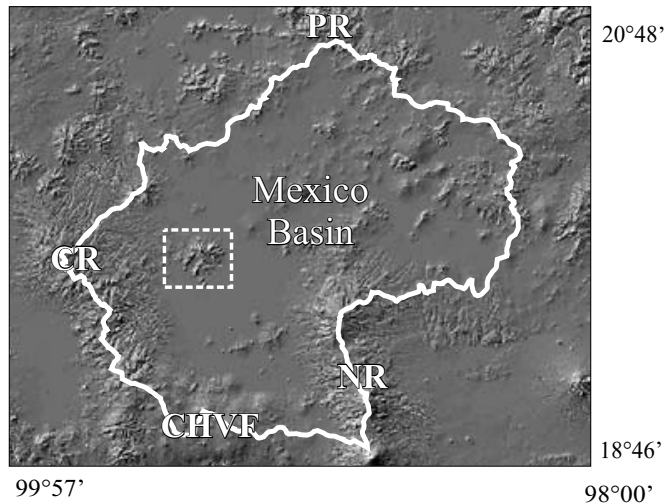

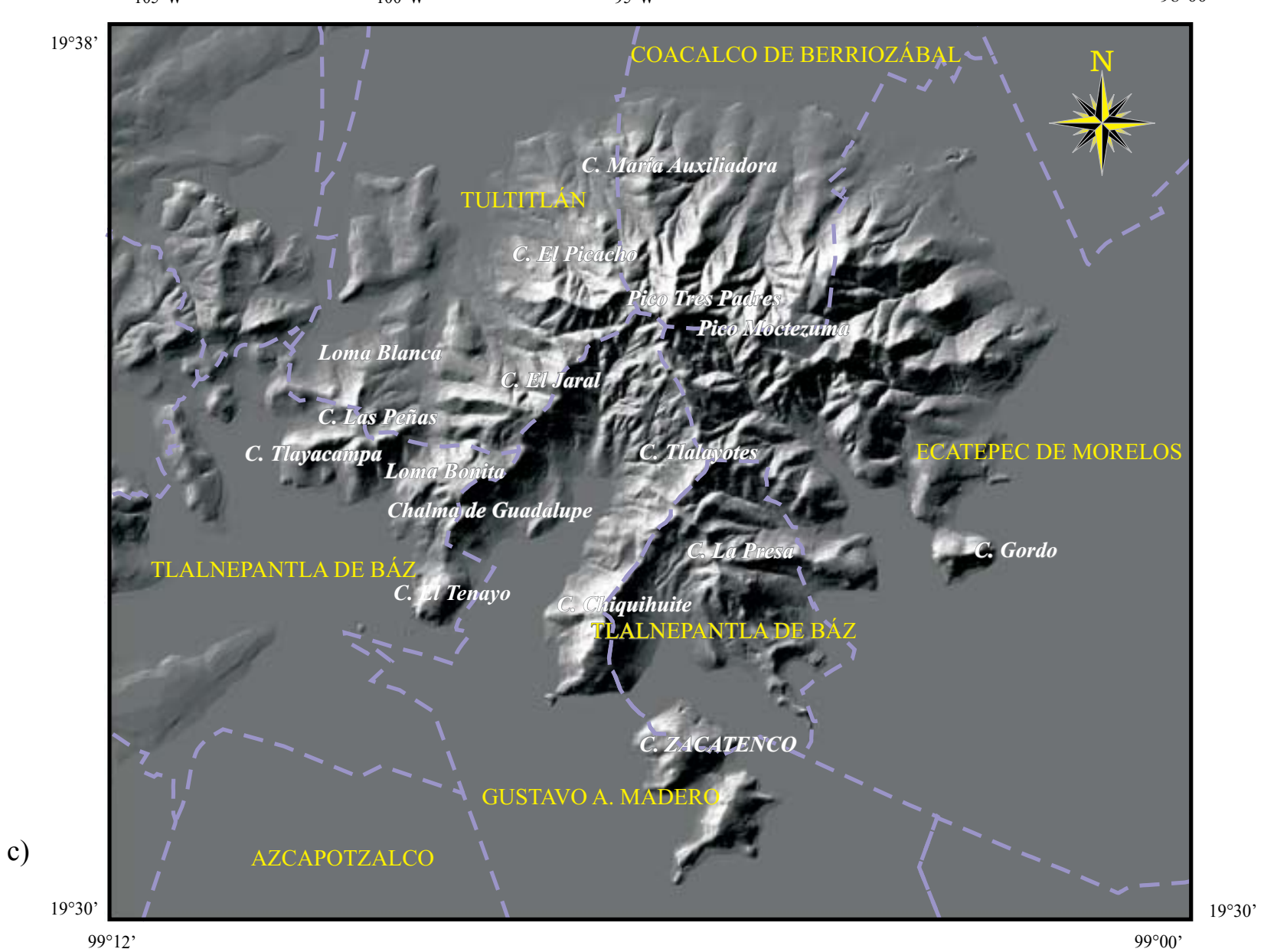

Figure 1. a) Location of the Trans-Mexican Volcanic Belt (TMVB). b) The Mexico Basin is in the north-central portion of the TMVB. Abbreviations are: CR Las Cruces, Range, PR Sierra de Pachuca, CHVF Chichinautzin Volcanic Field, and NR Sierra Nevada. c) Digital Elevation Model of the study area from topographic maps scale 1:50,000 of Instituto Nacional de Estadística Geografía e Informática (INEGI). The model shows the main morphological features as plains, hills, towns and localities in the region.

The GR consists of a cluster of domes and volcanoes with different sizes. At least fourteen volcanic units have been identified. The main volcanic structures are domes and collapsed stratovolcanoes (Servicio Geológico Metropolitano, 2003). The domes are El Tenayo, Chalma de Guadalupe, Tlayacampa, El Tecojote, and Chiquihuite. The stratovolcanoes are named Pico Tres Padres, Moctezuma, El Jaral, Picacho and La Presa. There are lava and pyroclas- tic flows, ash falls, avalanches and lahars associated with these volcanic structures. The lahars deposits are the most widespread volcanic deposits around the SG. The rocks are dacitic and rhyolitic in composition and minor intermediate rocks (Campa-Uranga, 1965; Servicio Geológico Metropolitano, 2003). Radiometric ages (K-Ar) on dacitic rocks have yielded ages of 14 and $16 \mathrm{Ma}$ (middle Miocene age) (Lozano-Barraza, 1968; Jacobo-Albarrán, 1985). 
The SG is transected by faults and fractures (LozanoBarraza, 1968; Mosser, 1975; 1992, Mosser et al.,1996; De Cserna et al., 1988; Vázquez-Sánchez and JaimesPalomera, 1989). In this work, we recognize three fault sets (Figure 2). The first and oldest fault system strikes $\mathrm{N}-\mathrm{S}$ and is characterized by a series of horst and graben structures and shear zones with dip-slip displacement (Figure 2a). According to the stratigraphic and structural relationships observed in the field, such faults correspond to a N-S regional fault studied in other regions of the TMVB (García-Palomo et al., 2002; Szynkaruk, 2004; AlanizÁlvarez and Nieto-Samaniego, 2005). The second fault and fracture system strikes NE-SW contains two prominent faults (Tenayuca and Chiquihuite), and is responsible for the formation of the Cuautepec graben located in the central portion of the SG (Mooser, 1992) (Figure 2b). The youngest fault system is a normal fault that strikes E-W and is located in the western portion of the SG. In that place, it forms the Barrientos graben (Mooser, 1992; Flores-Moro, 2006; Garcia-Palomo et al., 2006). The most conspicuous faults in the Barrientos Graben are the La Quebrada and
Tlayacampa and the resulting horsts are known as Chilpa and Tlayacampa (Figure 2c).

\subsection{Geomorphologic aspects}

The geomorphology of the study area was widely studied by Lugo-Hubp and Salinas-Montes (1996) and Fraustro, (1999). In both studies were related the geomorphology with natural hazard of GR. In this paper we analyzed some geomorphologic aspects relevant to the landslide phenomenon. The SG is an almost circular topographic feature, with circa $800 \mathrm{~m}$ altitude. The highest peaks are the Pico Tres Padres and Moctezuma, 3000 and 2930 msnm respectively, in the northern portion of the range. The smallest hills are known as El Tenayo (2470 masl), Chalma de Guadalupe (2700 masl), Tlalayotes (2680 masl), and El Jaral (2690 masl). The lowest slopes of the range are composed of rock fragments eroded from the highest parts (Figure 3a). We defined different morphological zones on the basis of the slope angles: slopes ranging between 0 and $15^{\circ}$, cor-

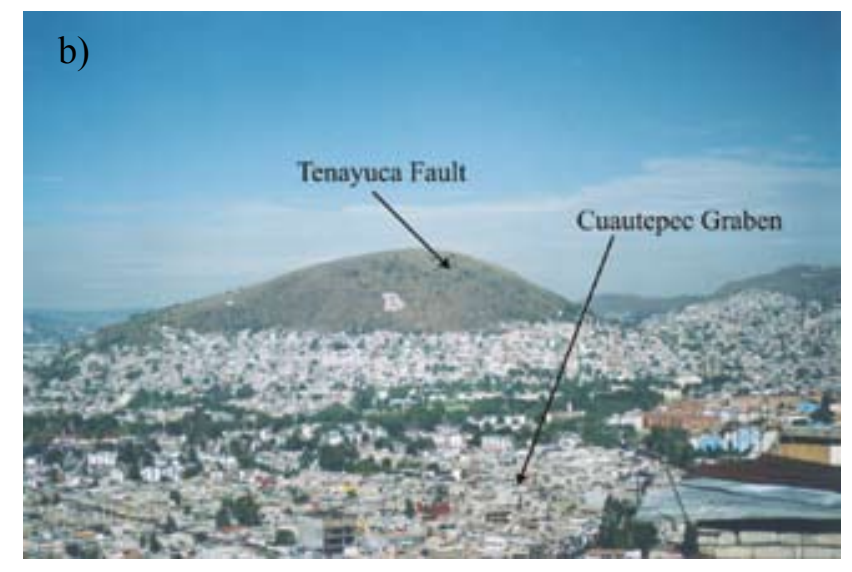

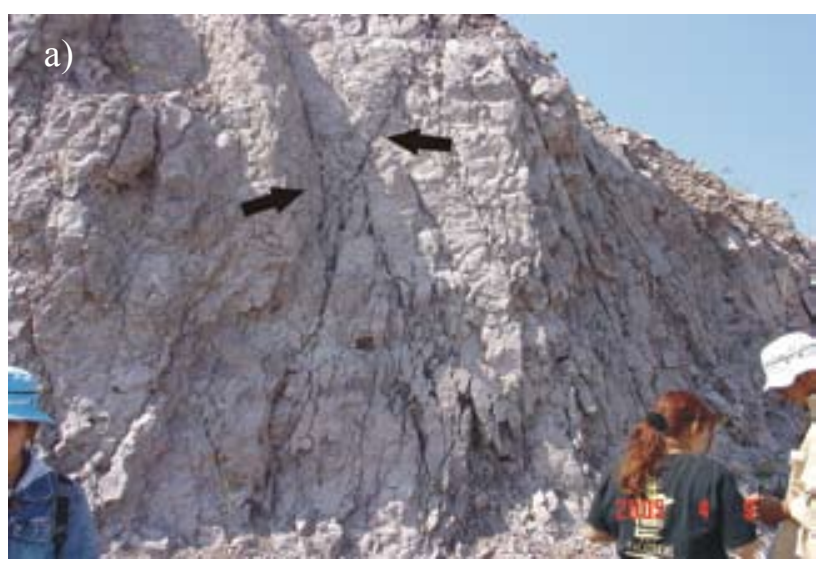

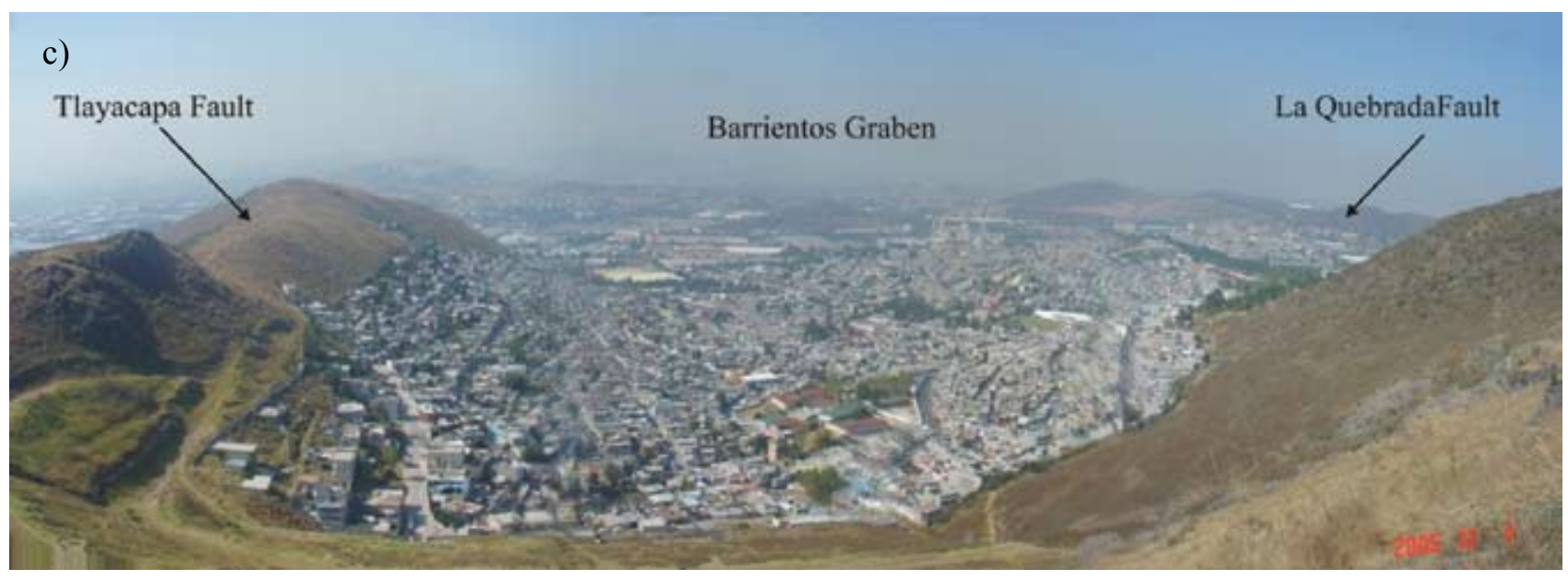

Figure 2. Faults features. a) Conjugate array of a N-S trending shear zone, affecting dacitic rocks. It shows the loose material with different size and shapes produced by the high fracture zone. b) Panoramic of Cuautepec graben and the NE-SW Tenayuca fault zone. c) View of E-W Barrientos graben, it show the Tlayacapa and La Quebrada faults. 


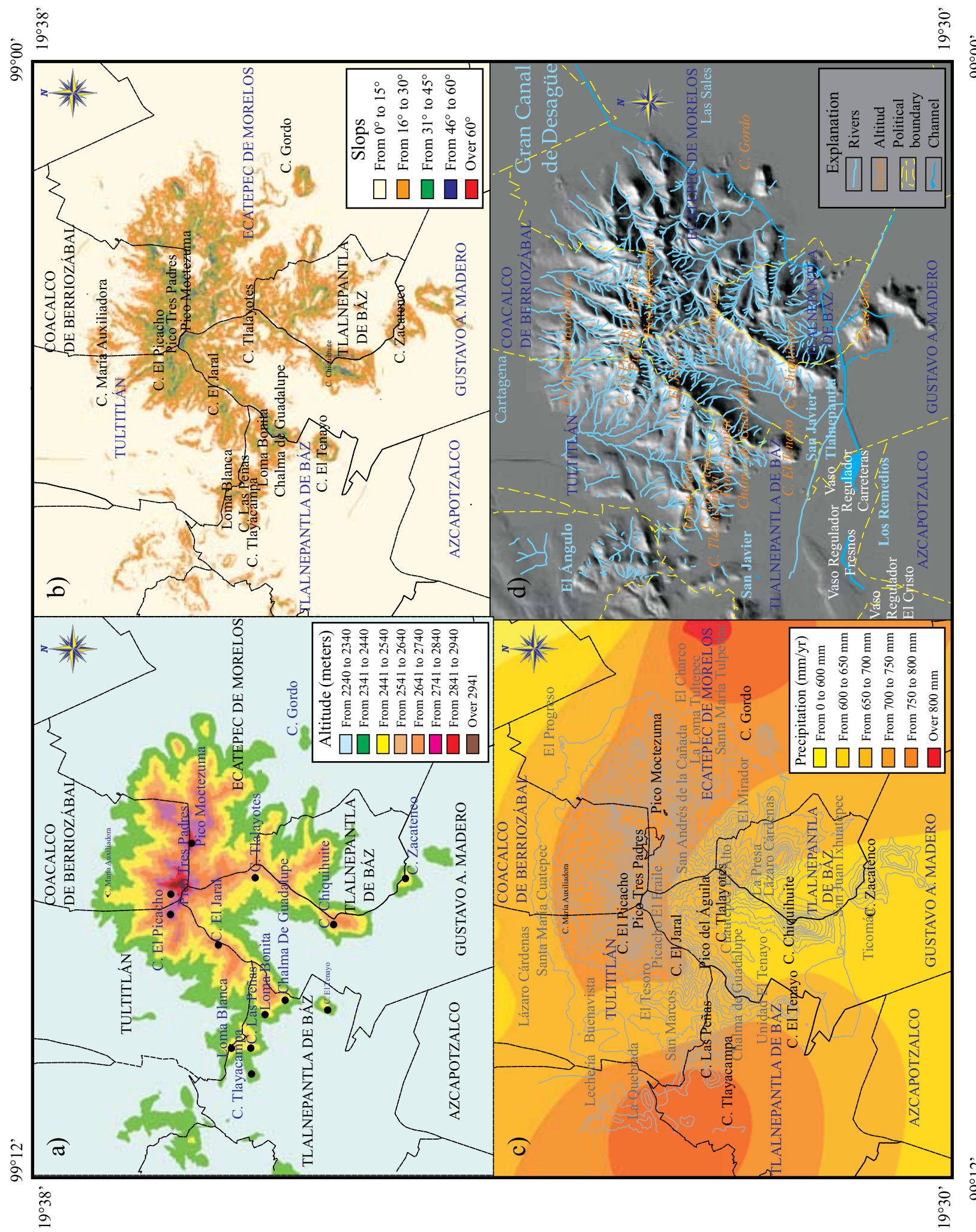




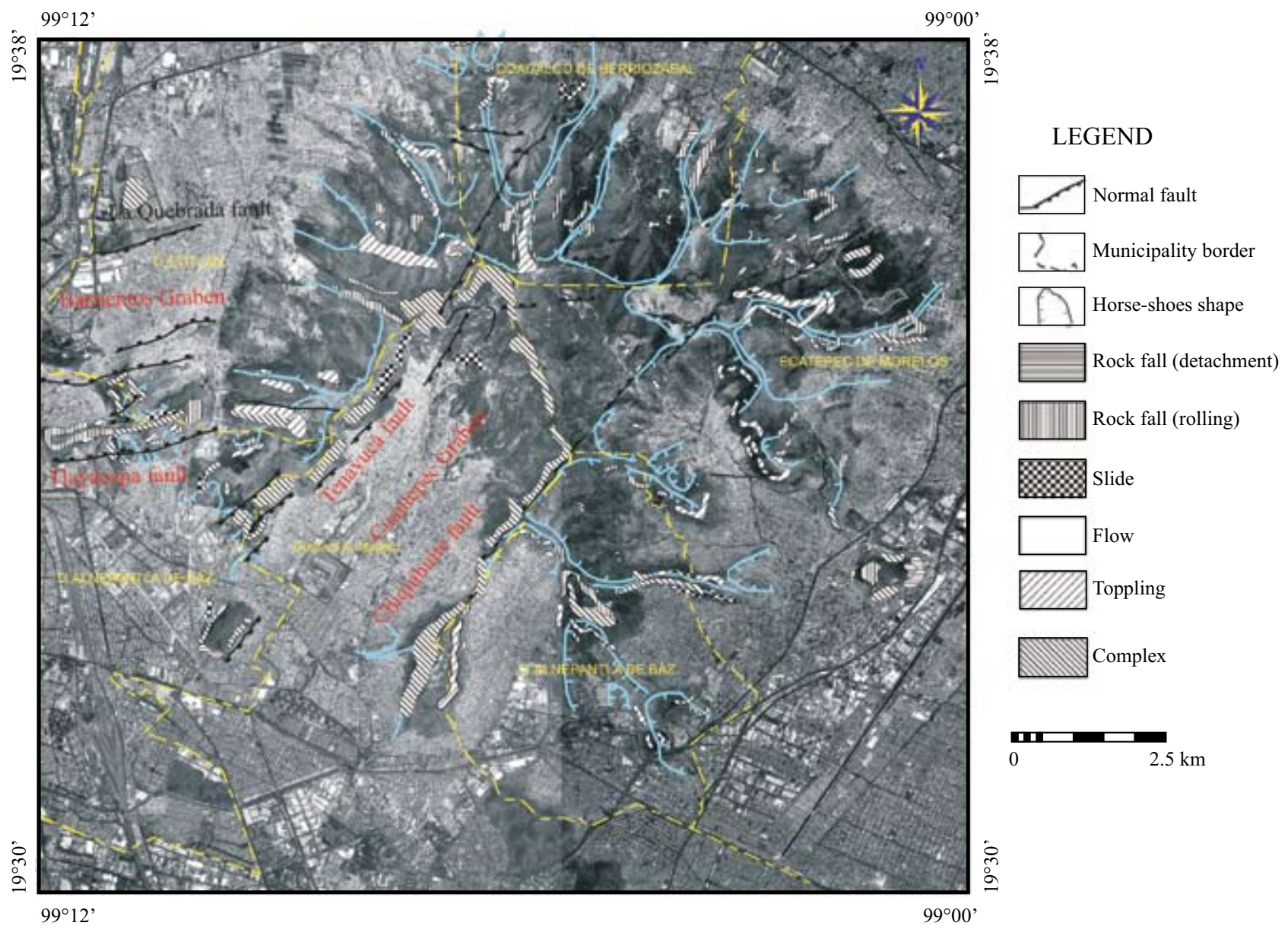

Figure 4. Shadow model relief showing the landslide inventory of Guadalupe Range and fault and horse-shoe structures related. The shades indicate types of landslides.

respond to the surrounding lacustrine plains and foot hills, slopes between $16^{\circ}$ and $30^{\circ}$ comprise the lowest angle slopes at Chiquihuite, Tenayo, María Auxiliadora, Cerro Gordo y Tlayacampa hills. Slopes ranging from $31^{\circ}$ to $45^{\circ}$ correspond to the central topographic prominences of $\mathrm{El}$ Picacho, Pico Tres Padres and Pico Moctezuma. Finally the range between $46^{\circ}$ and $60^{\circ}$ is located at the top and correspond to very steep scarps at the Chiquihuite, Chalma de Guadalupe and the surroundings of El Picacho, Pico Tres Padres, Moctezuma and normal fault that characterize the zone (Figure 3b).

In addition, the isohyetal line map made using different hydrometric stations located around the GR, indicates that the central portion has the highest values of precipitation 750 to $820 \mathrm{~mm} / \mathrm{yr}$, decreasing towards the peripheral zones $(740-700 \mathrm{~mm} / \mathrm{yr})$ and to the plain zone $(600 \mathrm{~mm} / \mathrm{yr})$. These values correspond to a zone with high elevation and steep slopes (Figure 3c).

On the other hand, SG has different types of drainage patterns, which are controlled by three main factors: 1) circular morphology of the GR, 2) former erosive landforms 3) faults and fractures (Salinas-Montes, 1994; Lugo-Hubp and Salinas-Montes, 1996). The main drainage pattern is radial, from the center of the SG to the lower and outer parts. The second pattern is a widely spaced dendritic pattern, controlled by semicircular concave erosive landforms. Finally, angular drainage is also present and is characterized by a river valley formed along fracture and fault traces, intercepted by short perpendicular tributaries, which run along secondary tectonic features (Figure $3 d)$.

\section{Results}

\subsection{Landslide inventory map}

We identified 206 landslide sites (Table 1). The most frequent slope failures occur in steep walls of lava flows where we recognized such mechanisms as toppling in $42 \%$ of the cases ( 86 sites) and rock falls $27 \%$ (53 sites). Failures are generally located on the head and flanks of horseshoe-shaped erosive landforms and fault scarpments, like at the Tenayuca and Chiquihuite faults, and at the Cuautepec graben, which is a depression with a large human concentration. 
Tabla 1. Movement mechanism recognized.

\begin{tabular}{lc}
\hline Movement mechanism & Number \\
\hline Rock fall (detachment) & 5 \\
Rock fall (rolling) & 53 \\
Slide & 11 \\
Flow & 11 \\
Toppling & 86 \\
Combined & 40 \\
Total & 206 \\
\hline
\end{tabular}

Other landslide mechanisms recognized in the area were: wedge failure, sliding on a single discontinuity, rotational, debris flow, creep, and differential erosion, or a combination of these mechanisms (Figure 5), which are less common and represent $31 \%$ of the total sites. Rotational landslides, debris flow, creep, and differential erosion take place mostly at sites with rocks of less strength or materials with lower compaction such as pyroclastic deposits.

We performed a classification of landslides, according to their frequency and the results show (Table 2) that
Ecatepec and Tlanepantla have the major number of landslide sites and Tultitlán, Coacalco and Gustavo A. Madero have the less sites. In the last forty years (1960-2000), as it was stated before, the population in the municipalities that share the SG has drastically increased, for example, Tlalnepantla has grown 7 times, $(105,447-721,415)$, Tultitlán 28 times $(15,479-432,141)$, Ecatepec 40 times $(40,815-1,622,697)$ Coacalco 63 times $(3,984-252,555)$ and Gustavo A. Madero 6 times $(744,905-4,264,350)$ (Table 3). On the other hand, the demographic expansion is verging towards the hills of the SG. Thus, Tultitlán has $2.08 \%$, Ecatepec 4.59\%, Gustavo A. Madero 5.19 \%, Coacalco $6.60 \%$ and Tlalnepantla $7.14 \%$ people living on hills of SG (Table 4). Considering the number and area of landslides and also the high population concentrations adjacent to SG, Tlalnepantla, Ecatepec and Gustavo A. Madero are the communities with the highest landslide hazard, followed by Coacalco and lastly by Tultitlán and Gustavo A. Madero. However, Gustavo A. Madero represents one of the most dangerous, due to its location under the scarps of the Tenayuca and Chiquihuite faults. In that zone, the conditions are highly favorable to generate landslides.
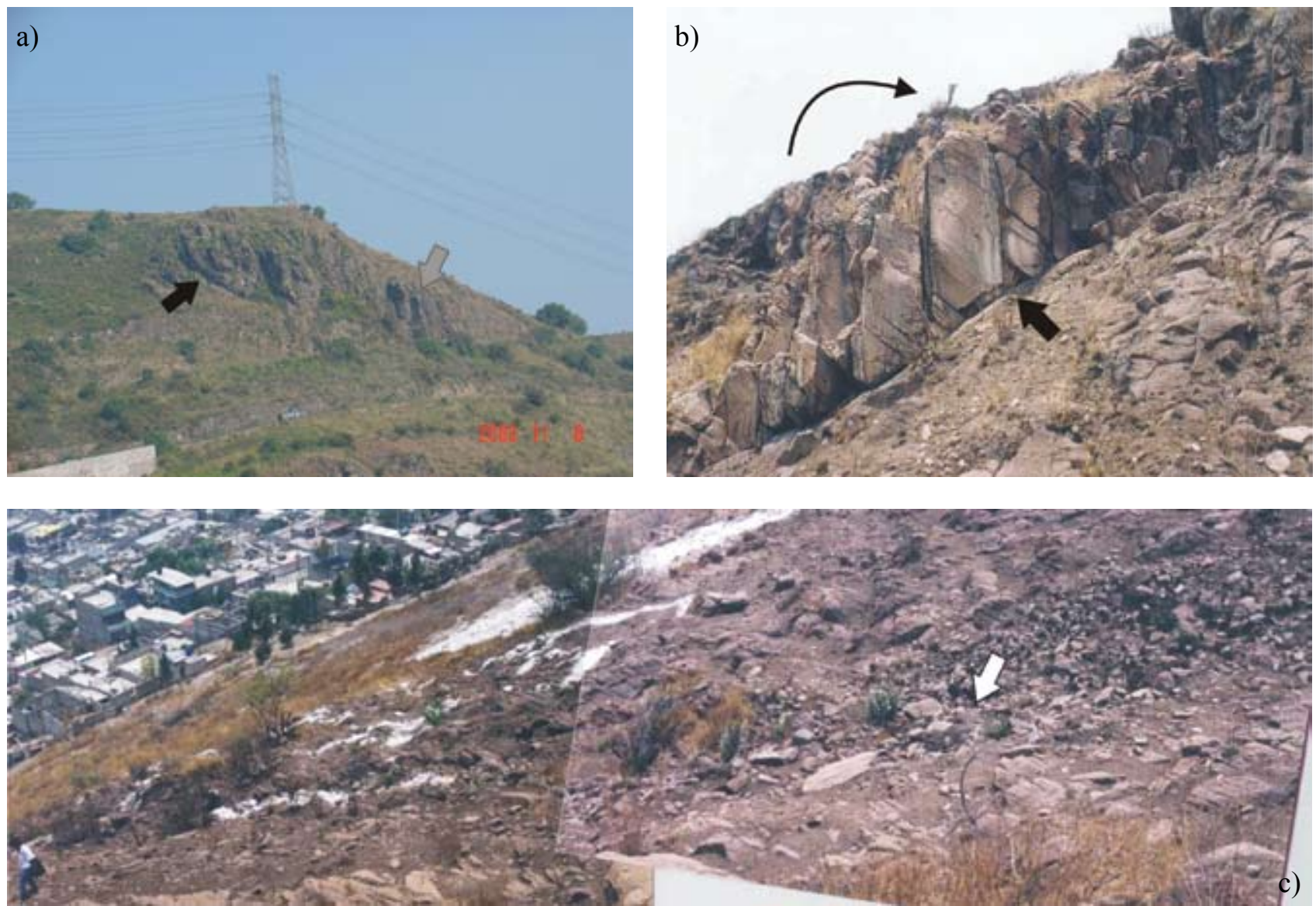

Figure 5. a) Complex landslides mechanisms, a rotational mechanism (black arrow), slides and domino like-structures (gray arrow). b) Complex landslide mechanisms, with a translational slide plane (thick arrow) and domino-like structures with a counter-clock movement (thin arrow). c) Rounded material on a steeply slop and close to the houses (white arrow). 
Tabla 2. Frequency and type of movement mechanism by municipalities

\begin{tabular}{|c|c|c|c|}
\hline Municipality & Movement mechanism & Number & $\operatorname{Area}\left(m^{2}\right)$ \\
\hline \multirow{6}{*}{$\begin{array}{l}\text { Tlalnepantla } \\
\text { (West) }\end{array}$} & Rock fall (detachment) & 1 & 40.72 \\
\hline & Rock fall (rolling) & 4 & 269.90 \\
\hline & Slide & 2 & 44.77 \\
\hline & Toppling & 7 & 122.00 \\
\hline & Flow & 4 & 14.00 \\
\hline & Combined & 11 & 486.14 \\
\hline \multirow{5}{*}{$\begin{array}{l}\text { Tlalnepantla de Báz } \\
\text { (East) }\end{array}$} & Rock fall (rolling) & 8 & 254.53 \\
\hline & Slide & 1 & 29.10 \\
\hline & Toppling & 16 & 349.98 \\
\hline & Flow & 2 & 11.36 \\
\hline & Combined & 8 & 345.47 \\
\hline \multirow{5}{*}{ Tultitlán } & Rock fall (rolling) & 7 & 372.93 \\
\hline & Slide & 1 & 35.70 \\
\hline & Toppling & 15 & 919.10 \\
\hline & Flow & 2 & 8.79 \\
\hline & Combined & 4 & 558.41 \\
\hline \multirow[t]{5}{*}{ Coacalco } & Rock fall (detachment) & 1 & 54.97 \\
\hline & Rock fall (rolling) & 11 & 449.93 \\
\hline & Slide & 2 & 134.25 \\
\hline & Toppling & 8 & 275.44 \\
\hline & Combined & 3 & 97.11 \\
\hline \multirow[t]{6}{*}{ Ecatepec } & Rock fall (detachment) & 3 & 105.00 \\
\hline & Rock fall (rolling) & 23 & 565.50 \\
\hline & Slide & 2 & 42.68 \\
\hline & Toppling & 36 & 800.37 \\
\hline & Flow & 3 & 1.56 \\
\hline & Combined & 7 & 348.83 \\
\hline \multirow[t]{3}{*}{ Gustavo a. Madero } & Slide & 3 & 237.69 \\
\hline & Toppling & 4 & 338.37 \\
\hline & Combined & 7 & 143.58 \\
\hline
\end{tabular}

\section{Conclusions}

SG is made of a cluster of dacitic domes and volcanoes, which are strongly affected, by faults and erosive processes forming horse-shoe shaped structures. Three fault systems have been recognized in the SG, and they have been active since the Miocene, first as strike-slip faults and subsequently with normal movement. The activity of these faults through time has generated zones very susceptible to landslide generation. The reasons are diverse, namely: 1) The faults in the region generate steep slopes $>30^{\circ}$, which overcome the friction angle of the granular or massive materials and promote landslides; 2) The fault zone is accompanied by a highly fractured zone that eases the generation of rock slides, rock falls and toppling; 3 ) Landslides are also facilitated by the presence of non-cohesive materials such as fault breccias and gouge, which allow the loss of fall-prone rocks (Figure 6a); 4) When the material is non-cohesive and fine grained (gouge fault), which is similar to clayey material, it permits translational or rotational landslides; 5) If the faulted rocks are permeable enough, water infiltration produces high pore pressure (Figure 6b).
Table 3. Population growing of the Municipality of Mexico state and Gustavo A. Madero during the last 40 years.

\begin{tabular}{|c|c|c|c|c|c|}
\hline & 1960 & 1970 & 1980 & 1990 & 2000 \\
\hline \multicolumn{6}{|c|}{ Coacalco de Berriozábal } \\
\hline & 3,984 & 13,197 & 97,353 & 152,082 & 252,555 \\
\hline \multicolumn{6}{|c|}{ Ecatepec de Morelos } \\
\hline & 40,815 & 216,408 & 784,507 & 1218,135 & $1^{\prime} 622,697$ \\
\hline \multicolumn{6}{|c|}{ Tlalnepantla de Baz } \\
\hline & 105,447 & 366,935 & 778,173 & 702,807 & 721,415 \\
\hline \multicolumn{6}{|c|}{ Tultitlán } \\
\hline & 15,479 & 52,317 & 136,829 & 246,464 & 432,141 \\
\hline \multicolumn{6}{|c|}{ Gustavo A. Madero } \\
\hline & 579,180 & 1'186,107 & $1 ’ 513,360$ & $1 ' 268,068$ & $1 ’ 235,542$ \\
\hline \multicolumn{6}{|l|}{ Total } \\
\hline & 744,905 & 1834,964 & 3’310,222 & $3 ’ 587,556$ & $4^{\prime} 264,350$ \\
\hline
\end{tabular}

Table 4 Percentage of population living on slops of mountain zone

\begin{tabular}{|c|c|c|c|c|}
\hline $\begin{array}{l}\text { Population } \\
2000\end{array}$ & $\begin{array}{l}\text { Total } \\
\text { area } \\
\mathbf{k m}^{2}\end{array}$ & $\begin{array}{l}\text { Urban } \\
\text { area } \\
\mathbf{k m}^{2}\end{array}$ & $\begin{array}{c}\text { Urban area on } \\
\text { mountain slops } \\
\text { km }^{2}\end{array}$ & $\begin{array}{c}\text { Urban Percentage } \\
\text { on mountain } \\
\text { slops }\end{array}$ \\
\hline \multicolumn{5}{|c|}{ Coacalco de Berriozábal } \\
\hline 252,555 & 32 & 15 & 1 & $6.60 \%$ \\
\hline \multicolumn{5}{|c|}{ Ecatepec de Morelos } \\
\hline $1,622,697$ & 120 & 87 & 4 & $4.59 \%$ \\
\hline \multicolumn{5}{|c|}{ Tlalnepantla de Báz } \\
\hline 721,415 & 69 & 56 & 4 & $7.14 \%$ \\
\hline \multicolumn{5}{|l|}{ Tutltitlán } \\
\hline 432,141 & 48 & 27 & 1 & $2.08 \%$ \\
\hline \multicolumn{5}{|c|}{ Gustavo A. Madero } \\
\hline $1 ’ 235542$ & 87 & 77 & 4 & $5.19 \%$ \\
\hline
\end{tabular}

The horse-shoe shaped erosive landforms are widespread in the Guadalupe Range, indicating old landslide processes in the region. Nowadays, horse-shoe shaped features are the origin of landslides because: 1) These features are located in elevated zones at the head of drainages, with steep slopes, highly fractured zones, affecting lava or pyroclastic flows and where high precipitation occurs. This facilitates landslides in the flanks or head zones of these structures with different mechanisms of failure as toppling and rock falls; 2) Their morphology controls and distributes the drainage pattern toward the main streams in the center of the structure, promoting mud and debris flows.

Our study supports a good correlation between faults and horse-shoes shape structures, and landslides, because the horse-shoes structures of the SG obey to tilting on the slopes caused by tectonic extension occurred in the Pliocene. On the other hand, the potential natural triggers of landslides in the region would be seismic activity and high precipitation.

In addition, to these natural slope conditions, the zone has suffered large anthropogenic modifications during the urban zone growth. The mining has modified the original slope and the construction of new houses inside abandoned 

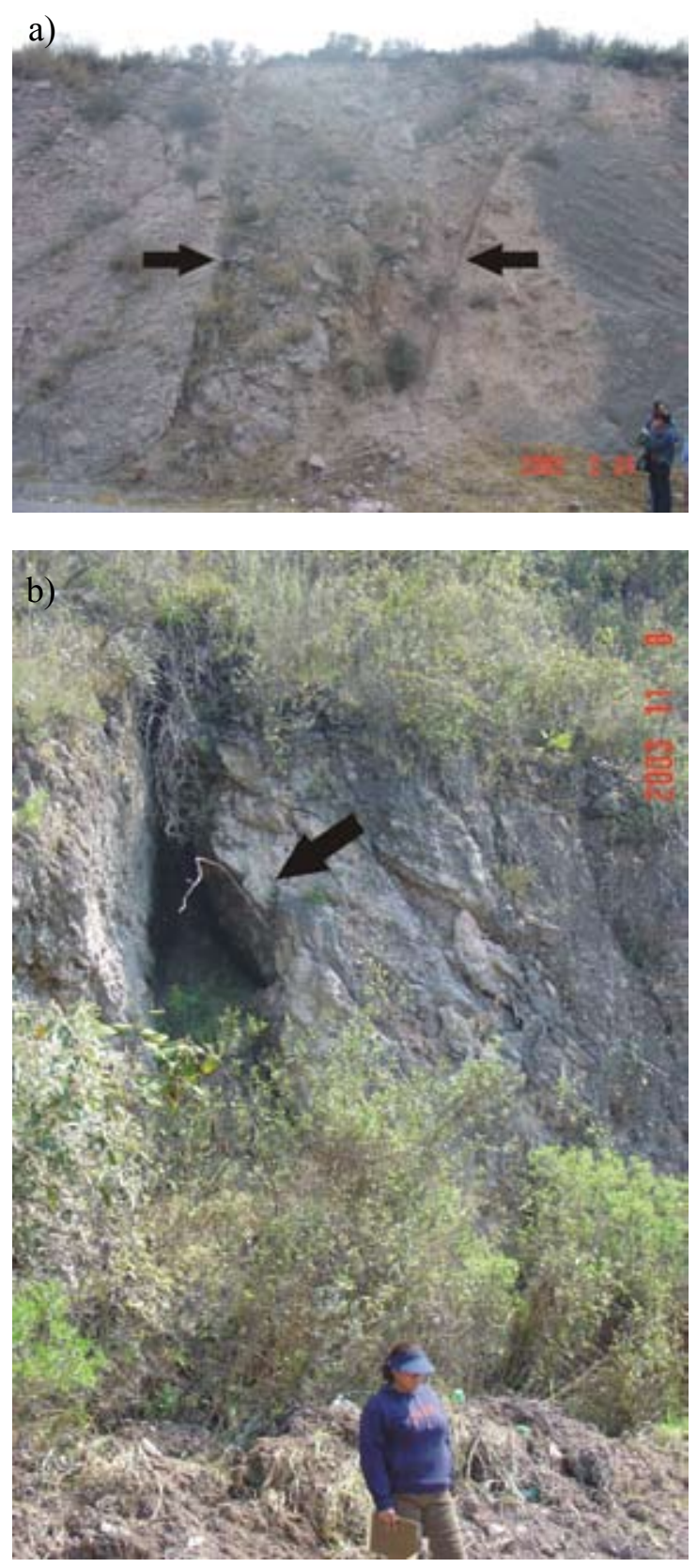

Figure 6. a) Crumbly wide NE-SW shear zone with angular blocks. The fault affected the debris avalanche deposits in the Barrientos Graben (black arrow indicates the wide fault zone). b) Wide aperture zone on a fault plane that promotes the infiltration of rainwater (black arrow show aperture zone).

open pits increases the landslide hazard (Figure 7). The vibration levels produced during construction, the pass of heavy vehicles, and deforestation are some of the anthropogenic factors that modified the original conditions and in most cases lead to failure.

We propose a tectonic origin as an explanation of the steep morphology zones at Guadalupe Ranges, due to the good correlation with landslide locations. The most characteristic case is present in the communities located in the fault scarps Tenayuca and Chiquihuite faults that form the Graben de Cuatepec. Likewise, the horse-shoes structures were made by tilting of the slopes during the normal phase. We have identified 206 hazards zones and two potential natural processes: seismic activity and pore water pressure. Anthropogenic factors such modifications of slope, vibrations, deforestation, and presence of residual waters, have also influenced the generation of landslides in the region. Moreover, in SG the most hazardous localities for landslides, where there is a high-density of population settled on hills, are Tlalnepantla, Ecatepec and Gustavo A. Madero, Tultitlán and finally Coacalco follow them. For this reasons, we make the following recommendations: First, to avoid construction in places close to landslide sites, especially on those declared by the Mexican government as ecologic reserves. Secondly, the codes for construction, and slope creation and modification, in sites close to steep slopes should be reviewed. Thirdly, to perform detailed geological and geotechnical studies, to identify the critical zones. It is also necessary to take steps to avoid fires on the vegetation cover; to properly manage and control residual water, especially in the neighborhoods at the top of hills and scarps. To control the free transit of heavy vehicles along roads, and finally give general information to the
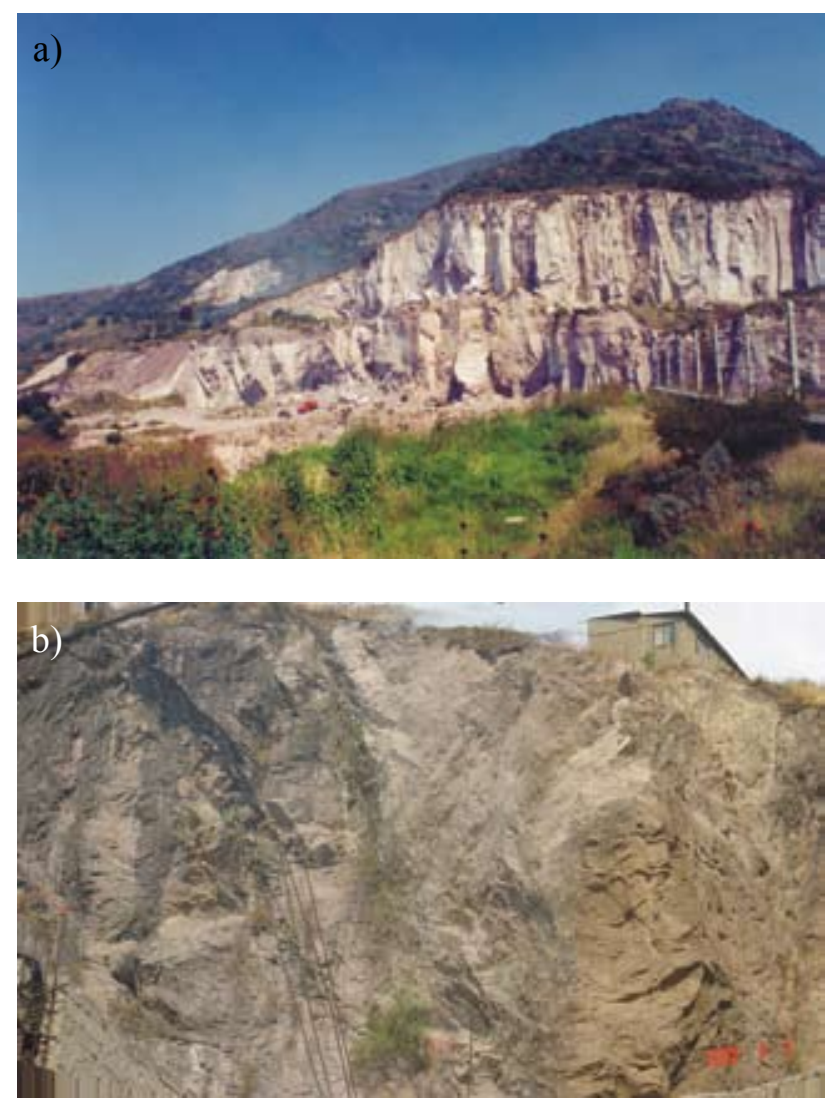

Figure 7. Anthropic modification of relief. a) Quarry zone, showing vertical walls and vehicles working near of the zone. b) House built adjacent to a steep wall (old quarry). 
population living on high-hazards areas to avoid activities that affect slope stability.

\section{Acknowledgements}

We are thankful to Luis Wintergerst T. (Director general de Protección Civil del Distrito Federal), authorities of Instituto de Protección Civil, Estado de México, and Dr. Gustavo Tolson (Director del Instituto de Geología de la Universidad Nacional Autónoma de México). The paper was improved thanks to suggestions of Drs. Jose Luis Macías, Jose Luis Arce, Juan Manuel Espíndola and two anonymous readers. We appreciate the technical support of Ana Maria Rocha.

\section{References}

Alaníz-Álvarez, S.A., Nieto-Samaniego, A. F, 2005, El sistema de fallas Taxco-San Miguel de Allende y la Faja Volcánica Transmexicana, dos fronteras tectónicas del centro de México activas durante el Cenozoico, Boletín conmemorativo del centenario de la Sociedad Geológica Mexicana, Tomo LVII(1), 65-82.

Campa-Uranga, M. F., 1965, Breve Análisis Petrográfico de la Sierra de Guadalupe: Instituto Politécnico Nacional, Escuela Superior de Ingeniería y Arquitectura, tesis licenciatura, $61 \mathrm{p}$.

Carlos-Valerio, V., 2003, Estudio de Estabilidad de Taludes y Evaluación del Riesgo Geotécnico en el Cerro del Tenayo, Estado de México: Universidad Nacional Autónoma de México, Facultad de Ingeniería, tesis licenciatura, $155 \mathrm{p}$.

De Cserna, Z., De la Fuente-Dutch, M., Palacios-Nieto, M., Triay, L., MitreSalazar, L.M. y Mota-Palomino, R., 1988, Estructura Geológica, Gravimetría, Sismicidad y Relaciones Neotectónicas Regionales de la Cuenca de México: Universidad Nacional Autónoma de México, Boletín del Instituto de Geología., 104,171 p.

Espinosa-Hernández, G., 2004, Zonificación de los Peligros Geológicos en la Ladera SW del Cerro del Chiquihuite: Universidad Nacional Autónoma de México, Facultad de Ingeniería, tesis de licenciatura, $79 \mathrm{p}$.

Flores-Moro, G.V, 2006, Geometría Estructural y Cinemática de la Fosa de Barrientos, Zona Centro Poniente de la Cuenca de México. Instituto Politécnico Nacional, Escuela Superior de Ingeniería y Arquitectura, tesis licenciatura, $75 \mathrm{p}$.

Fraustro, M. O., 1999, Derrumbes, deslizamientos y expansión lateral del suelo provocados por la sismicidad en el graben de Cuatepec: Región sur de la Sierra de Guadalupe, en la Ciudad de México. Investigaciones Geográficas, Boletín del Instituto de Geografía, 39, 15-29 p.

García-Palomo, A., Macias, J., L. Tolson, J., Valdez, G., Mora, J.C., 2002, Volcanic Stratigraphy and Geological Evolution of the Apan Region, East-Central Sector of the Trans-Mexican Volcanic Belt: Geofísica Internacional, 41 (2), 133-150.

García-Palomo, A., Flores-Moro, G. V, Carlos-Valerio V., Galván, A., López-Miguel C., Hernández B., 2006, Geometría Estructural y Cinemática de la Fosa de Barrientos. V Reunión Nacional de Ciencias de la Tierra,13-16 de Septiembre Puebla, Pue.

Hutchinson, J. N., 1988, General Report: Morphological and Geotechnical Parameters of Landslides in Relation to Geology and Hydrogeology: Proceedings of the Fifth International Symposium on Landslides, Vol. I, edited por by Christopher Bonnard.
Instituto Nacional de Estadística, Geografía e Informática (INEGI), 1988, Carta topográfica Cuautitlán, E14-A29, escala 1: 50 000: México, D. F. Secretaria de Programación y Presupuesto, Instituto Nacional de Estadística, Geografía e Informática, 1 mapa.

Jacobo-Albarrán, J. J., 1985. Estudio Petrogenético de las Rocas de la Porción Central del Eje Neovolcánico: Instituto Mexicano del Petróleo, Reporte Interno.

Lozano-Barraza, L., 1968, Geología de la Sierra de Guadalupe, México, D. F.: Escuela Superior de Ingeniería y Arquitectura, Instituto Politécnico Nacional, tesis licenciatura, $39 \mathrm{p}$.

Lugo-Hubp, J., y Salinas Montes A., 1996, Geomorfología de la Guadalupe Ranges (al norte de la Ciudad de México) y su Relación con Peligros Naturales: Universidad Nacional Autónoma de México: Instituto de Geología, Revista Mexicana de Ciencias Geológicas, 13, 240-251.

Mooser, F., 1975, Historia Geológica de la Cuenca de México: Memoria de las Obras del Sistema de Drenaje Profundo, Departamento del Distrito Federal, México.

Mooser, F., 1992, Nuevo Mapa Geológico del Sur-Poniente del Valle de México: Simposium Experiencias Geotécnicas en la Zona Poniente del Valle de México: Sociedad Mexicana de Mecánica de Rocas, 5-15.

Mooser, F., Montiel A., Zúñiga, A.,1996, Nuevo Mapa Geológico de las Cuencas de México, Toluca y Puebla: Estratigrafía, Tectónica Regional y Aspectos Geotérmicos. Comisión Federal de Electricidad.

Nieto-Obregón J., Herrera Castañeda S., Rosales Mendoza, C. y Delgado Granados H., 2000, Evaluación de Peligros Gravitacionales y Riesgos Asociados en el Cerro Cabeza de Águila, Delegación Gustavo A. Madero, Simposio Internacional sobre Riesgos Geológicos y Ambientales en la Ciudad de México, México, D. F. 16-20 de octubre del 2000, p. 113.

Salinas-Montes, A., 1994, Geomorfología de la Sierra de Guadalupe y Riesgos Naturales: Universidad Nacional Autónoma de México, Facultad de Filosofía y Letras, tesis licenciatura, $102 \mathrm{p}$.

Servicio Geológico Metropolitano, 2001, Proyecto "Evaluación de los Peligros Geológicos Existentes en los Sitios San Juan y Candelaria Ticomán, Delegación Gustavo A. Madero"Gobierno del Distrito Federal, Delegación Gustavo A. Madero.

Servicio Geológico Metropolitano, 2003, Evaluación y Zonificación de los Peligros Geológicos por Deslizamientos de las Laderas de la Sierra de Guadalupe, Estado de México: Instituto de Protección Civil, Estado de México.

Servicio Sismológico Nacional, 2001, Reporte de sismos en la Republica Mexicana (en línea): Instituto de Geofísica: Servicio Sismológico Nacional, www.ssn.unam.mx

Szynkaruk, E., 2004, Tectonic Implication of Geomorphologic and Structural Characteristics of the Morelia-Acambay Fault System, Central Trans-Mexican Volcanic Belt: Universidad Nacional Autónoma de Mexico, tesis doctoral, 108 p.

Vazquez-Sanchez, E., Jaimes-Palomera, R., 1989, Geología de la Cuenca de México, Geofísica Internacional, 28 2, 133-190 p.

Manuscript received: October 15, 2005

Corrected manuscript received: January 19, 2006

Manuscript accepted: October 25, 2006 